\title{
PENGUKURAN MINAT MAHASISWA BERDASARKAN TEORI HOLLAND
}

\author{
Iriani Indri Hapsari \& Herdiyan Maulana \\ email: ririnanwar@yahoo.com \\ Psikologi, FIP Universitas Negeri Jakarta
}

\begin{abstract}
Abstrak: Penelitian ini bertujuan untuk mengetahui bagaimana minat mahasiswa Fakultas Ilmu Pendidikan (FIP) berdasarkan teori peminat Holland. Penelitian ini merupakan penelitian deskriptif dengan menggunakan kuesioner yang dimodifikasi dari tes inventori minat Holland. Penelitian ini dilakukan di Fakultas Ilmu Pendidikan UNJ angkatan 2008-2011, Maret sampai Desember 2012. Populasi penelitian ini adalah mahasiswa Fakultas Ilmu Pendidikan dari delapan program studi/jurusan mulai dari angkatan 2008 sampai dengan 2011 dengan sampel berjumlah 200 mahasiswa yang dibagi menjadi dua kelompok yaitu mahasiswa FIP dari psikologi dan mahasiswa FIP non psikologi. Teknik pengambilan sampel menggunakan teknik purposive nonrandom sampling. Berdasarkan hasil pengolahan data diketahui bahwa sebagian besar mahasiswa memiliki minat yang dominan pada tipe enterpreneurship, kemudian pada bidamg sosial, dan paling sedikit pada tipe realistik. Hal ini menunjukkan, minat mahasiswa FIP UNJ masih sesuai dengan keberadaan mereka di lingkungan.
\end{abstract}

Kata kunci: minat, pengukuran minat, teori Holland

\section{MEASURING THE STUDENTS' INTEREST BASED ON HOLLAND THEORY}

\begin{abstract}
This research aims to explore the students' interestat the School of Education, State University of Jakarta. The interest model was based on Holland interest theoritical framework. Descriptive analysis was used to analyze the data from eight dapartments at school of education. The respondents involved 200 students from 2008 to 2011 recruitment. The data were collected through purposive nonrandom sampling technique. The results show that majority of respondents have entepreuners interest, then social, and realistic interest the fewest. The result shows that majority interest of FIP students matches with their academic background.
\end{abstract}

Keywords: interest, interest measurement, Holland theory

\section{PENDAHULUAN}

Perkembangan ilmu pengetahuan dan teknologi dewasa ini memiliki implikasi terhadap semakin maraknya pengembangan minat lintas ilmu pengetahuan (transdisipliner) yang bermuara pada semakin bervariasinya aktivitas dan jenis lapangan kerja yang dapat dipilih oleh individu kelak. Aktivitas tersebut menuntut individu untuk dapat berkarya secara efektif dan efisien sehingga akan menghasilkan kinerja yang optimal. Salah satu aspek yang turut berkontribusi dalam meningkatkan kinerja individu adalah adanya kesesuaian antara bidang pekerjaan dan minat individu. Minat akan memandu individu dalam melakukan tugas pekerjaan sesuai dengan karakteristik pekerjaan yang dihadapi. Lebih lanjut, pada tahap yang lebih awal, diagnosa terhadap minat individu akan membantu individu dalam proses belajar di perguruan tinggi sekaligus mempersiapkan diri dalam menentukan jenis pekerjaan yang sesuai dengan tipologi minat.

Minat telah dikenal sebagai predisposisi yang efektif untuk meningkatkan kualitas pembelajaran individu. Prestasi yang maksimal tidak hanya dapat dicapai melalui kecerdasan semata, namun adannya minat turut berkontribusi secara signifikan dalam memacu prestasi individu dalam berbagai bidang. Menurut beberapa ahli psikologi, minat adalah gejala psikologis yang menunjukan adanya pemusatan perhatian individu terhadap suatu obyek yang disebabkan adanya perasaan senang/suka. Minat juga dapat dipahami sebagai kekuatan (forces) yang 
mendorong individu untuk memberikan perhatian lebih pada situasi, aktivitas, atau objek tertentu lainnya secara intens.

Dunia pendidikan tinggi idealnya mampu menghasilkan para lulusan-lulusan perguruan tinggi yang tidak hanya siap secara intelektual di bidang keilmuan nya masing-masing tapi juga harus mampu memahami potensi diri, termasuk menyadari minat yang dimilikinya hingga kemudian mampu memandu individu dalam menjalankan tugas dengan baik.

Pengukuran dan pemetaan minat telah dikenal lama sebagai bagian dari prosedur psikodiagnostika dalam rangka mengungkap salah satu unsur dari potensi diri dalam diri manusia. Penatalaksanaan diagnosa psikologis terhadap minat dilakukan melalui serangkaian tes tertulis dalam bentuk inventori yang bersandar pada teori-teori minat.

Inventori adalah metode pengukuran aspek psikologis dalam bentuk serangkaian pernyataan atau pertanyaan, di mana individu diminta untuk memberikan respon melalui jawaban-jawaban singkat. Tes inventori adalah tes-tes yang terutama menggunakan paper and pencil. Tes inventori merupakan selfreport questionnare untuk menentukan karakteristikkarakteristik kepribadian, minat (interested), sikap (attitude), dan nilai-nilai (value). Tes inventori sangat berguna untuk mengetahui karakteristik kepribadian seperti minat, penyesuaian diri, motivasi, hingga kecenderungan sikap-sikap negatif seperti prasangka.

Berdasarkan masalah di atas, maka dapat dirumuskan masalah, yaitu "bagaimana minat mahasiswa FIP UNJ serta mendapatkan proses diagnosa psikologis minat pada mahasiswa FIP UNJ berdasarkan teori model minat Holland?"

Minat adalah aktifitas atau tugas-tugas yang membangkitkan perasaan ingin tahu, pengertian dan memberi kesenangan serta kenikmatan. Hakikat dan kekuatan dari minat dan sikap merupakan aspek penting kepribadian yang dapat mempengaruhi prestasi pendidikan dan pekerjaan, relasi, hobi dalam kehidupan sehari-hari (Holland dalam Anastasi, 2007).

Minat dapat menjadi indikator dari kekuatan seseorang di area tertentu di mana dia akan termotivasi untuk mempelajarinya dan menunjukkan kinerja yang tinggi. Bakat akan sulit berkembang dengan baik apabila tidak diawali dengan adanya minat pada bidang yang akan ditekuni.

Minat pada orang dewasa menentukan aturan penting dalam perkembangan pribadi dan prilaku (Chauhan, 1978). Minat merupakan hal penting untuk mengerti individu dan menuntun aktivitas dimasa yang akan datang. Secara umum, minat dibagi menjadi tiga, yaitu: (1) minat pribadi, (2) minat situasi, dan (3) minat dalam ciri psikologi (Krapp, Hidi, dan Renninger dalam Pintrich \& Schunk, 1996).

Minat pribadi diartikan sebagai karakteristik kepribadian seseorang yang relatif stabil, yang cendrung menetap pada diri seseorang. Minat pribadi biasanya dapat langsung membawa seseorang pada beberapa aktifitas atau topik yang spesifik. Minat pribadi dapat dilihat ketika seseorang menjadikan sebuah aktivitas atau topik sebagai pilihan untuk hal yang pasti, secara umum menyukai topik atau aktivitas tersebut, menimbulkan kesenangan pribadi serta topik atau aktivitas yang dijalani memiliki arti penting bagi seseorang tersebut. Minat situasi merupakan minat yang sebagian besar dibangkitkan oleh konsisi lingkungan. Sedangkan minat dalam ciri psikologi merupakan interaksi dari minat pribadi seseorang dengan ciri-ciri minat lingkungan. Renninger menjelaskan bahwa minat pada definisi ini tidak hanya pada karena seseorang lebih menyukai sebuah aktivitas atau topik, tetapi karena aktivitas atau topik tersebut memiliki nilai yang tinggi dan mengetahui lebih banyak mengenai topik atau aktivitas tersebut.

Aspek-aspek minat adalah sebagai berikut: (1) aspek kognitif, berdasarkan atas pengalaman pribadi dan apa yang pernah dipelajari baik di rumah, sekolah dan masyarakat serta dan berbagai jenis media massa; (2) aspek afektif, konsep yang membangun aspek kognitif, minat dinyatakan dalam sikap terhadap kegiatan yang ditimbulkan minat. Berkembang dari pengalaman pribadi dari sikap orang yang penting yaitu orang tua, guru dan teman sebaya terhadap kegiatan yang berkaitan dengan minat tersebut dan dari sikap yang dinyatakan atau tersirat dalam berbagai bentuk media massa terhadap kegiatan itu; (3) aspek psikomotor, berjalan dengan lancar tanpa perlu pemikiran lagi, urutannya tepat. Namun kemajuan tetap memungkinkan sehingga keluwesan dan keunggulan meningkat meskipun ini semua berjalan lambat (Hurlock, 1978).

Teori model minat dibagi menjadi 6 kategori. Teori ini bisa membantu individu untuk memilih karir dalam kehidupannya berdasarkan model yang sesuai dengan kepribadian serta lingkungannya. Enam model minat tersebut adalah model (1) realistic, (2) investigatif, (3) artistic, (4) social, (5) enterprising, dan (6) conventional (Sharf, 1992).

Petama, realistic. Lingkungan yang sesuai untuk tipe realistik adalah yang berkaitan dengan fisik seperti bekerja dengan peralatan, mesin , memanipulasi 
obyek atau binatang. Dalam hal ini, diperlukan kompetensi teknik untuk dapat melakukan pekerjaan memperbaiki mesin, memperbaiki kerusakan elektronik, menyetir mobil atau truk, berburu binatang dan lainnya yang membutuhkan kemampuan fisik dalam lingkungannya. Kemampuan dalam bekerja lebih penting daripada kemampuan berinteraksi dengan orag lain. Lingkungan yang sesuai adalah bekerja di pabrik, bangunan, dan lain sebagainya. Lingkungan bekerja untuk tipe realistik lebih rawan kecelakaan dan sakit fisik dibandingkan tipe lainnya.

Dilihat dari kepridiannya, tipe realistik senang menggunakan peralatan dan mesin dalam melakukan pekerjaan dan hobinya. Biasanya mereka mengembangkan kompetensinya dalam bidang teknik seperti teknik pertanian, teknik mesin, teknik sipil dll. Tipe ini bekerja secara lebih praktis dan mengutamakan kekuatan fisik serta mekanik dibanding deskripsi teori atau ilmu abstrak. Tipe ini lebih mementingkan uang, kekuatan dan status dibandingkan hubungan relasi dengan orang lain.

Pekerjaan ini umumnya terdapat pada laki-laki dibandingkan perempuan. Tetapi tipe ini bisa saja terdapat pada perempuan terutama bila memiliki ayah dan saudara laki-laki yang memiliki tipe realistik. Tipe realistik pada wanita bisanya terdapat pada pekerjaan design bunga, penjahit, arsitektur dll.

Kedua, investigasi. Berdasarkan lingkungannya, tipe ini cocok untuk orang yang senang menyelesaikan suatu masalah secara kreatif dan berfikir secara komplek serta abstrak seperti dalam bidang matematika dan science. Lingkungan pekerjaan yang menawarkan pekerjaan pada tipe ini adalah pekerjaan yang membutuhkan keterampilan berfikir analisis seperti programmer komputer, ahli fisika, ahli matematika, ahli biologis, guru science, peneliti dan manager pengembangan.untuk menyelesaikan masalah diperlukan kemampuan intelektual yang memadai sesuai dengan bidang pekerjaannya, perlu berfikir logis dan metodis. Mereka tidak terlalu memerlukan relasi sosial maupun mesin. Misalnya programmer computer membutuhkan berfikir logis untuk menyelesaikan masalah. Berbeda dengan opertair komputer bekerja dengan mesin dan bekerja untuk mengoperasikan mesin (tipe realistik).

Sedangkan dari segi kepribadian, orang yang memiliki tipe investigatif senang menyelesaikan suatu masalah seperti puzzle dan juga senang dengan tantangan yang memerlukan kemampuan intelektualnya. Seperti seseorang yang senang bisa menyelesaikan soal matimatika, fisika dll. Senang membaca dan berdiskusi tentang hal-hal terkait science, senang mengikuti pelatihan matematika, fisika, biologis, kimia, geologi dan lainnya. Mereka bekerja secara mandiri dan tidak memerlukan bantuan orang lain dalam menyelesaikan masalahnya.

Ketiga, artistic. Pada tipe artistik lingkungannya lebih bersifat terbuka dan bebas, membutuhkan kreativitas serta ekspresi personal. Lingkungan pekerjaan yang cocok adalah lingkungan yang membebaskan seseorang berkreasi seperti sebagai musisi, artis, penulis. Mereka bebesa menentukan pakaian, tempat, waktu sesuai keinginannya . Tipe ini lebih mengembangkan orang untuk mengekspresikan dirinya dan emosinya secara personal dibandingkan ekspresi logisnya.

Tipe orang artistik mereka menyukai hal-hal yang bisa mengekspresikan dirinya secara bebas dan tidak sistematik untuk berkreasi dalam musik, seni serta menulis. Terkadang seseorang membutuhkan alat untuk mengekpresikan seninya seperti piano, biola. Mereka menginginkan mengembangkan kemampuannya dalam hal bahasa, seni, musik dan menulis. Sifat original dan kreativitas merupakan hal yang utama pada tipe ini. Pada tipe ini tidak menyukai teknik dalam menulis tetapi lebih menyukai menulis fiksi atau puisi.

Keempat, social. Lingkungan pada tipe social mendorong seseorang untuk lebih fleksibel dan saling memahami satu sama lain. Seseorang bisa bekerja dalam hal menolong permasalahan orang lain, masalah karir, mengajar, memotivasi dalam hal spiritual dan tanggung jawab sosial.Lingkungan tipe sosial biasanya terdapat orang-orang yang idealis, baik, friendly dan generous.biasanya terdapat pada bidang pendidikan, sosial servis, dan profesi kesehatan mental mislanya bekerja di sekolah, guru pendidikan luar biasa, konselor perkawinan, psikologi konseling, terapi wicara, psikiater.

Seseorang dengan tipe sosial senang bila bisa menolong orang lain seperti sebagai guru, menolong permasalahan orang lain baik masalah pribadi maupun karir. Mereka senang berdiskusi dan bekerjasama dibandingkan hanya mendelegasikan pada orang lain. Mereka menghindari pekerjaan yang berkaitan dengan mesin, mereka senang bekerja dengan pekerjaan yang membutuhkan keterampilan sosial dan keterampilan verbal seperti sebagai pendidik, dalam bidang kesejahteraan dan kesehatan mental.

Kelima, enterprising. Lingkungan tipe enterprising adalah dimana seseorang bisa mengatur dan mengajak orang lain dalam mengatur organisasi atau 
tujuan personal. Dalam hal ini yang paling penting adalah keuangan dan ekonomi isu serta bagaimana menanggung resiko untuk bisa berkembang lebih maju.Pada tipe ini biasanya orang-orangnya cenderung percaya diri, sosiable serta asertif. Hal utama adalah promosi, kekuatan, marketing dan penjualan. Contoh lingkungan kerjanya sales, asuransi, pelobi, manajemen bisnis, manajemen restoran, real estate dan politis. Pekerjaan ini untuk mendapatkan status, kekuasaan dan kesejahteraan.

Kesejahteraan adalah hal utama bagi seorang enterprising. Mereka senang bersama orang lain dan senang menggunakan keterampilan verbal untuk menjual, mengajak serta memimpin. Mereka cenderung asertif dan populer, dan senang mencoba menjadi seorang pemimpin. Mereka senang bekerjasama dengan orang lain tapi sebagai pemimpin atau marketing dibandingkan untuk menolong orang lain.

Keenam, conventional. Organisasi dan perencana merupakan lingkungan yang tepat untuk tipe conventional. Pekerjaan yang sesuai adalah lingkungan perkantoran terutama bagian administrasi, sekretaris ataupun bendahara. Kompetensi yang sesuai untuk lingkungan conventional adalah keterampilan clerical, kemampuan mengorganisasi sesuatu, kemampuan untuk mengikuti intruksi.

Orang dengan tipe conventional senang dengan keteraturan dan taat pada aturan. Biasanya mereka senang bekerja di kantor untuk mendapatkan gaji dan tinggal mengikuti aturan - aturan pekerjaan yang harus dilakukan atau bersifat prosedural. Aktivitas yang dilakukan lebih berkaitan dengan verbal dan numerik yang sistematis. Hubungan dengan orang lain biasanya langsung berkaitan dengan tugas dan organisasi dalam menyelesaikan masalah. Contohnya ; seorang akuntan, bankir, sekretaris, analis biaya, auditor, ahli statistik.

Terdapat empat hal penting dalam mengkonsep dan menggunakan model Holland (Holland dalam Sharf, 1992). Pertama, kongruen, maksudnya adalah adanya hubungan antara sifat individu dengan lingkungan tempat ia berada untuk bekerja, melakukan hobi dan lainnya. Semakin terdapat kesamaan antara sifat kepribadian dengan lingkungannya maka akan semakin konruen hubungannya. Sebaliknya, semakin banyak ketidaksamaan antara sifat kepribadian dan lingkungannya maka akan semakin tidak konruen hubungannya. Contohnya, orang yang memiliki sifat social maka dia akan lebih senang berada di lingkungan yang bergerak dalam bidang social. Orang yang sifatnya realistic tidak terlalu tertarik berada di lingkungan kerja sosial, mereka akan kaku dan membutuhkan waktu dalam beradaptasi di lingkungan kerja sosial.

Kedua, diferensiasi, menjelaskan bahwa satu model minat dengan model lainnya memiliki perbedaan yang jelas, memiliki ciri dan spesifikasi masing-masing. Setiap individu memiliki kecenderungan untuk mendekati salah satu model minat tertentu. Namun, seringkali terdapat individu yang merasa mendekati beberapa model minat yang berbeda. Menurut Holland, walaupun seseorang memiliki beberapa minat tetapi tetap mengarah lebih dominan ke salah satu model yang bias dilihat dari skor yang paling tinggi, karena model minat Holland membedakan masing-masing model minat secara jelas. Contohnya, seseorang yang memiliki kesenangan di bidang social maka akan lebih mengarah ke model sosial.

Ketiga, konsistensi, maksudnya tentang adanya kesamaan dan ketidaksamaan dari model minat Holland. Beberapa tipe memiliki kecenderungan yang hampir sama atau mendekati dalam hal sifat maupun kepribadian seperti orang yang sifatnya social biasanya mereka juga senang dengan orang yang besifat artistic atau berada di lingkungan artistic (masih sejalan). Sedangkan dengan yang tipe realistic, tipe sosial biasanya memiliki banyak ketidaksamaan (bertentangan). Oleh karena itu, Semakin memiliki banyak kesamaan, maka semakin akan menunjukkan kekonsistenannya. Tetapi semakin tidak ada kesamaan maka akan tidak konsisten sifat dan bidang pekerjaannya.

Keempat, identitas, menjelaskan bahwa seseorang ketika sudah memiliki identitas yang jelas tentang tujuan karirnya, maka ia akan memahami sifat dirinya dan lingkungan yang sesuai untuk dirinya. Selanjutnya akan merencanakan, mempersiapkan dirinya sesuai dengan identitasnya dan siap menghadapi segala konsekuensi dengan pilihannya. Memilih pekerjaan tanpa perencanaan yang jelas akan membingungkan identitasnya sendiri. Contohnya individu yang akan menjadi psikolog, tapi mereka tidak mengetahui dan mencari informasi tentang apa itu psikolog, kerjanya apa, bagaimana cara menjadi psikolog maka ia akan mengalami kebingungan identitas.

Inventori adalah suatu metode untuk mengadakan pengukuran sejenis kuesioner, perbedaannya dalam kuesioner responden menulis jawaban yang relative panjang, sedangkan inventori responden memberi jawaban dengan memberi tanda cek, lingkaran atau tanda yang lain yang berupa jawaban-jawaban singkat. 
Metode pengukuran minat yang digunakan dalam penelitian ini mengggunakan teknik angket atau kuesioner, karena teknik ini sangat efektif dan efisien dalam pengggunaan waktu. Tes inventori adalah testes yang terutama menggunakan paper and pencil. Tes inventori merupakan self report Questionnare, untuk menentukan karakteristik-karakteristik kepribadian, minat (interest), sikap (attitude), dan nilai-nilai (values). Tes inventori sangat berguna untuk mengetahui karakteristik kepribadian seperti minat, penyesuaian diri, motivasi, dan prasangka. Namun perlu di ingat bahwa alat-alat tes yang digunakan umumnya tidak ada yang sempurna dan masing-masing tes hanya menjelaskan satu atau beberapa aspek kepribadian.

\section{METODE PENELITIAN}

Tujuan dari penelitian ini adalah untuk menelusuri bagaimana minat mahasiswa FIP UNJ serta mendapatkan proses diagnosa psikologis minat pada mahasiswa FIP UNJ berdasarkan teori model minat Holland.

Kuesioner yang digunakan merupakan modifikasi dari beberapa tes inventori minat Holland yang dikembangkan dari teori model minat Holland yang dikenal dengan model RIASEC atau kepanjangan dari realistic, investigatif, artistic, social, entepreunership, dan covensional. Alat ukut inventori ini telah diterjemahkan ke dalam bahasa Indonesia dan telah melalui uji keterbacaan dan validasi isi.

Penelitian ini dilakukan di Fakultas Ilmu Pendidikan UNJ angkatan 2008-2011 pada bulan Maret sampai bulan Desember 2012 dari tahap penyusunan proposal sampai pelaporan hasil penelitian.

Populasi penelitian ini adalah seluruh mahasiswa FIP UNJ angkatan 2008-2011 yang terdiri dari delapan jurusan atau program studi yaitu psikologi, pendidikan luar sekolah (PLS), Bimbingan Konseling (BK), Pendidikan guru Sekolah dasar (PGSD), Pendidikan Luar Biasa (PLB), Manajemen pendidikan (MP), Pendidikan anak Usia dini (PAUD) dan teknologi Pendidikan (TP).

Sampel dalam penelitian ini dibagi menjadi dua kelompok yaitu kelompok FIP non psikologi dan kelompok FIP dari psikologi. Hal ini dilakukan terkait latar belakang peneliti sebagai dosen psikologi, sehingga peneliti ingin mengetahui minat mahasiswa psikologi untuk pengembangan mahasiswa di lingkungan peneliti mengajar. Namun, karena tidak hanya Jurusan psikologi saja yang menjadi sampel melainkan FIP secara umum, maka peneliti juga mengambil sampel dari semua Jurusan di luar psikologi di lingkungan FIP.
Jumlah sampel penelitian ini keseluruhan berjumlah 200 mahasiswa, yang terdiri dari 100 mahasiswa psikologi dan 100 dari berbagai Jurusan di FIP dengan berbagai angkatan. Teknik Pengambilan sampel penelitian ini menggunakan teknik purposive nonrandom sampling.

Instrumen yang digunakan dalam penelitian ini adalah menggunakan kuesioner. Teknik kuesioner merupakan teknik pengumpulan data yang dilakukan dengan cara memberi seperangkat pertanyaan atau pernyataan tertulis kepada responden untuk dijawab (Arikunto, 2006).

Setelah semua data terkumpul, langkah selanjutnya adalah menganalisis data, sehingga dari data-data tersebut dapat ditarik suatu kesimpulan. Teknik analisis data yang digunakan dalam penelitian ini adalah dengan menggunakan analisa statistika deskriptif yang menghasilkan prosentase nilai skor minat mahasiswa berdasarkan jurusan. Analisa ini dilakukan dengan menggunakan program microsoft excell dan SPSS versi 16 untuk mendapatkan perhitungan statistika deskriptif dari data minat mahasiswa.

\section{HASIL DAN PEMBAHASAN}

\section{Hasil Penelitian}

Untuk mengetahui minat mahasiswa UNJ dapat diketahui minat mahasiswa FIP UNJ secara umum berdasarkan teori minat Holland yang membagi minat menjadi enam yaitu realistis, investigasi, artistic, social, enterprising (bisnis) dan convensional atau biasa disingkat dengan RIASEC. Jumlah mahasiswa yang memiliki berbagai minat berdasarkan teori minat Holland dapat dilihat dalam tabel 1.

Tabel 1. Tipe Minat Mahasiswa FIP UNJ Berdasarkan Teori Minat Holland

\begin{tabular}{|c|c|c|c|c|c|}
\hline \multirow{2}{*}{$\begin{array}{c}\text { Tipe } \\
\text { Minat }\end{array}$} & \multicolumn{4}{|c|}{ Responden } & \multirow{2}{*}{ Jml } \\
\cline { 2 - 5 } & $\begin{array}{c}\text { FIP non } \\
\text { Psikologi }\end{array}$ & $\%$ & $\begin{array}{c}\text { FIP dari } \\
\text { Psikologi }\end{array}$ & $\%$ & \\
\hline R & 2 & 1 & 2 & 1 & 4 \\
\hline I & 6 & 3 & 7 & 3,5 & 13 \\
\hline A & 5 & 2,5 & 4 & 2 & 9 \\
\hline S & 12 & 6 & 15 & 7,5 & 27 \\
\hline E & 64 & 32 & 67 & 33,5 & 131 \\
\hline C & 11 & 5,5 & 5 & 2,5 & 16 \\
\hline Total & 100 & 50 & 100 & 50 & 200 \\
\hline
\end{tabular}

Berdasarkan hasil pengambilan data pada mahasiswa FIP di lingkungan Universitas Negeri Jakarta dengan jumlah subjek sebanyak 200 mahasiswa, maka diketahui bahwa tipe minat 
mahasiswa UNJ dominan berada pada tipe enterprising atau kewirausahaan (65,5\% atau 131 mahasiswa). Hal tersebut terlihat pada kedua kelompok yaitu Mahasiswa FIP non psikologi dan mahasiswa FIP dari psikologi yang keduanya dominan berminat di bidang enterprising dan memiliki prosentase yang tidak jauh berbeda. Mahasiswa FIP dari psikologi sebesar 33,5 \% atau 67 mahasiswa dan mahasiswa FIP non psikologi sebesar $32 \%$ atau 64 mahasiswa.

Tipe minat berikutnya yang mahasiswa FIP UNJ minati adalah tipe minat sosial yaitu sebesar 13,5\% atau ada 27 mahasiswa. Antara mahasiswa FIP dari psikologi dan non psikologi prosentasi minat tipe sosial juga tidak berbeda jauh. Mahasiswa FIP dari psikologi sebesar 7,5 \% dan mahasiswa FIP non psikologi sebesar $6 \%$. Sedangkan tipe minat yang paling sedikit diminati mahasiswa FIP UNJ adalah tipe realistic yaitu hanya $2 \%$ atau 4 mahasiswa saja yaitu 2 mahasiswa dari FIP psikologi dan 2 mahasiswa dari FIP non psikologi.

\section{Pembahasan}

Dari hasil deskripsi data yang sudah dipaparkan sebelumnya menunjukkan bahwa mahasiswa FIP UNJ memiliki tipe minat terbesar dalam hal entreprising atau kewirausahaan. Menurut Holland, seseorang yang memiliki tipe enterprising akan sesuai berada di suatu lingkungan dimana seseorang bisa mengatur dan mengajak orang lain dalam mengatur organisasi atau tujuan personal. Dalam hal ini yang paling penting adalah terkait tentang isu keuangan dan ekonomi serta bagaimana menanggung resiko untuk bisa berkembang lebih maju. Pada tipe ini biasanya orang-orangnya cenderung percaya diri, sosiable serta asertif. Hal utama yang bisa dilakukan adalah promosi, kekuatan, marketing dan penjualan. Contoh lingkungan kerjanya sales, asuransi, pelobi, manajemen bisnis, manajemen restoran, real estate dan politis. Pekerjaan ini untuk mendapatkan status, kekuasaan dan kesejahteraan.

Tipe kepribadian seseorang dengan tipe Enterprising adalah mengutamakan kesejahteraan. Mereka senang bersama orang lain dan senang menggunakan keterampilan verbal untuk menjual, mengajak serta memimpin. Mereka cenderung asertif dan populer, dan senang mencoba menjadi seorang pemimpin. Mereka senang bekerjasama dengan orang lain tapi sebagai pemimpin atau marketing dibandingkan untuk menolong orang lain. Sifat seseorang dengan tipe minat biasanya bersifat gigih, mudah menyesuaikan diri, percaya diri, optimis, pengambil keputusan, energik, popular, spontan dan siap menanggung resiko.

Fakultas Ilmu Pendidikan sebagai salah satu fakultas yang mendidik para mahasiswanya untuk menjadi seorang pendidik akan lebih sesuai bila mahasiswanya lebih memiliki tipe minat sosial dibandingkan tipe minat enterprising. Hal ini terkait dengan lingkungan sosial yang sesuai untuk para pendidik yang mampu mendorong seseorang untuk lebih fleksibel dan saling memahami satu sama lain. Para pendidik pada umumnya berperan dalam hal menolong permasalahan orang lain, masalah karir, mengajar, memotivasi dalam hal spiritual dan tanggung jawab sosial. Pada lingkungan tipe sosial biasanya terdapat orang-orang yang idealis, baik, friendly dan generous yang biasanya terdapat pada bidang pendidikan dan sosial servis, dan profesi kesehatan mental seperti bekerja di sekolah, guru pendidikan luar biasa, konselor perkawinan, psikologi konseling, terapi wicara, psikiater.

Dari hasil penelitian ini mahasiswa yang memiliki tipe sosial sebesar 27 mahasiswa atau sekitar 13,5 \% dari 200 mahasiswa. Hal ini jauh lebih kecil dibandingkan mahasiswa yang berminat di bidang entreprising. Namun begitu, menurut Holland, lingkungan kerja dan tipe kepribadian antara seseorang yang memiliki tipe Enterprising dan tipe lingkungan sosial masih memiliki hubungan yang erat dan bisa saling bersinergi atau memiliki derajat konsistensi yang tergolong tinggi. Hal ini menunjukkan bahwa seseorang yang memiliki tipe minat enterprising masih sesuai bila berada di lingkungan sosial dan berkumpul dengan orang-orang yang memiliki sifat kepribadian sosial. Begitupun sebaliknya bila seseorang yang memiliki tipe sosial berada dilingkungan entreprising dan berkumpul bersama orang-orang yang memiliki sifat kepribadian di bidang wirausaha, maka ia masih bisa menyesuaikan dirinya di lingkungan tersebut.

Berbeda halnya bila tipe minat mahasiswa yang dominan merupakan tipe minat realistik, hal ini bertolak belakang dan akan lebih sulit untuk berada di lingkungan sosial karena lingkungan yang sesuai untuk tipe realistik adalah lingkungan yang berkaitan dengan fisik seperti bekerja dengan peralatan, mesin , memanipulasi obyek atau binatang. Dalam hal ini diperlukan kompetensi teknik untuk dapat melakukan pekerjaan memperbaiki mesin, memperbaiki kerusakan elektronik, menyetir mobil atau truk, berburu binatang dan lainnya yang membutuhkan kemampuan fisik dalam lingkungannya. Kemampuan dalam bekerja lebih penting daripada kemampuan berinteraksi dengan orang lain. Lingkungan yang sesuai bagi 
tipe realistic adalah bekerja di pabrik, bangunan dll. Lingkungan bekerja untuk tipe realistik lebih rawan kecelakaan dan sakit fisik dibandingkan tipe lainnya. Kepribadian tipe realistik senang menggunakan peralatan dan mesin dalam melakukan pekerjaan dan hobinya. Biasanya mereka mengembangkan kompetensinya dalam bidang teknik seperti teknik pertanian, teknik mesin, teknik sipil dll. Tipe ini bekerja secara lebih praktis dan mengutamakan kekuatan fisik serta mekanik dibanding deskripsi teori atau ilmu abstrak. Tipe ini lebih mementingkan uang, kekuatan dan status dibandingkan hubungan relasi dengan orang lain. Hal tersebut menunjukkan bahwa tipe realistic sangat lemah konsistensinya dengan tipe sosial. Mahasiswa FIP UNJ yang memiliki tipe minat realistic hanya 4 orang atau sekitar $2 \%$ saja.

Oleh karena itu, mahasiswa FIP UNJ yang dominan memiliki tipe enterprising dapat dikatakan masih sesuai berada di lingkungan Fakultas Ilmu Pendidikan yang berlatar belakang lingkungan sosial dan sesuai bagi orang yang memiliki kepribadian tipe sosial. Bila dijumlahkan antara mahasiswa yang memiliki tipe minat enterprising dan tipe minat sosial berjumlah $79 \%$. Hal ini menunjukkan bahwa mayoritas mahasiswa FIP UNJ masih memiliki kesesuaian atau kongruen antara minat dan lingkungan tempat mereka mempelajari suatu ilmu yang akan menjadi bekal bagi karir mereka sebagai seorang pendidik. Hanya sedikit yang memiliki tipe realistic, yang berarti memiliki ketidaksesuaian antara minat mereka dengan lingkungan mereka saat ini yaitu di FIP, mereka akan lebih sesuai bila berada di jurusan yang bernuansa teknikal.

\section{Implikasi}

Penelitian sederhana ini menunjukkan bahwa sebagian besar mahasiswa FIP UNJ mayoritas memiliki tipe minat enterprising. Walaupun antara tipe minat sosial dan tipe minat enterprising memiliki kekonsistenan pada level tinggi yang menunjukkan keduanya dapat saling menyesuaikan diri bila berada di lingkungan keduanya, sebaiknya tetap menjadi perhatian bagi para pimpinan fakultas dan para dosen agar dapat memberikan kegiatan-kegiatan yang tidak hanya fokus pada bidang pendidikan saja yang umum dilakukan para pendidik. Namun, perlu dipikirkan untuk memberikan kegiatan yang dapat mewadahi minat mereka di bidang enterprising. Kegiatankegiatan tersebut sebaiknya dapat menjembatani antara minat mereka di bidang enterprising dan bidang pendidikan yang menjadi tujuan dari fakultas ilmu pendidikan. Apalagi saat ini sedang marak dikembangkannya karakter kewirausahaan pada peserta didik dari berbagai bidang. Hal ini menjadi keunggulan bagi FIP yang memiliki mahasiswa yang banyak berminat di bidang kewirausahaan atau enterprising.

Selain itu, stake holder Fakultas Ilmu Pendidikan juga perlu memikirkan kegiatan intrakulikuler dan ekstrakulikuler pada mahasiswa yang memiliki tipe minat yang bertolak belakang atau lemah dan medium konsistensinya dengan bidang sosial seperti tipe minat realistik atau investigatif, agar mereka tetap bisa menyesuaikan diri mereka di bidang pendidikan.

\section{PENUTUP}

\section{Kesimpulan}

Berdasarkan analisis data yang dilakukan dapat disimpulkan bahwa tipe minat mahasiswa FIP UNJ didominasi pada tipe minat enterprising. Hal ini menunjukkan bahwa mahasiswa FIP UNJ masih sesuai berada di lingkungan FIP yang berlatar belakang lingkungan sosial dan lebih sesuai bagi orang yang memiliki tipe minat sosial, karena antara tipe minat sosial dan enterprising memiliki kekonsistenan hubungan yang berada di level tinggi

\section{Saran}

Saran yang dapat diberikan sehubungan dengan penelitian ini adalah sebagai berikut. Pertama, penelusuran tipe minat mahasiswa sebaiknya dilakukan pada tahap awal penerimaan mahasiswa, agar pihak Universitas dan Fakultas bisa lebih memetakan minat mahasiswa dan menyesuaikan tipe minat mahasiswa dengan lingkungan yang lebih sesuai yaitu berada di FIP. Kedua, memaksimalkan potensi mahasiswa yang banyak memiliki minat di bidang enterprising dalam rangka mengembangkan karakter enterprising di bidang pendidikan dalam kegiatan intrakulikuler maupun ekstrakulikuler.

\section{DAFTAR PUSTAKA}

Anastasi, A \& Urbina, S. (2007). Tes psikologi Edisi Ketujuh. Jakarta ; PT Indeks

Arikunto, S. (2006). Prosedur penelitian: suatu pendekatan praktik. Jakarta: Rineka Cipta.

Echols, J \& Shadily, H. (2000). Kamus Inggris Indonesia. Jakarta : PT Gramedia

Hurlock, E.B (1978). Child development (6th ed). Toky: McGraw Hill. Kogakusha, LTD.

Papalia. (2008). Human development; Bagian I s/d IV. Jakarta: Kencana Prenada Media Group.

Sharf, R (1992). Applying career development theory to counseling. California: Brooks/Cole publishing Company. 
Silvia, P. J. (2006). Exploring the personality of interest. New York: Oxford University Press.

The Holland Model. Personality and work environment Guide. www.handwriting.com. Diakses pada tanggal 28 Februari 2012

Hidi, S. (1990). Interest and its contribution as a mental resource for learning. Review of educational research, vol.60 no.4.(winter, 1990). P.549-571. 